University of Nebraska - Lincoln

DigitalCommons@University of Nebraska - Lincoln

Distribution of psocids (Psocoptera) in temperature gradients in stored wheat

James E. Throne

USDA-ARS, Manhattan, KS, james.throne@ars.usda.gov

Paul W. Flinn

USDA-ARS

Follow this and additional works at: https://digitalcommons.unl.edu/usdaarsfacpub

Throne, James E. and Flinn, Paul W., "Distribution of psocids (Psocoptera) in temperature gradients in stored wheat" (2013). Publications from USDA-ARS / UNL Faculty. 2060.

https://digitalcommons.unl.edu/usdaarsfacpub/2060

This Article is brought to you for free and open access by the U.S. Department of Agriculture: Agricultural Research Service, Lincoln, Nebraska at DigitalCommons@University of Nebraska - Lincoln. It has been accepted for inclusion in Publications from USDA-ARS / UNL Faculty by an authorized administrator of DigitalCommons@University of Nebraska - Lincoln. 


\title{
Distribution of psocids (Psocoptera) in temperature gradients in stored wheat
}

\author{
James E. Throne*, Paul W. Flinn \\ USDA, Agricultural Research Service, Center for Grain and Animal Health Research, 1515 College Avenue, Manhattan, KS 66502, USA
}

\section{A R T I C L E I N F O}

\section{Article history:}

Accepted 15 July 2013

\section{Keywords:}

Behavior

Liposcelis bostrychophila

Liposcelis entomophila

Liposcelis paeta

Stored-product insect

\begin{abstract}
A B S T R A C T
Psocids have become important pests of stored products during the last two decades, but little is known about their behavior or ecology. We examined distribution of Liposcelis bostrychophila Badonnel (Psocoptera: Liposcelididae), Liposcelis entomophila (Enderlein), and Liposcelis paeta (Pearman), three of the main psocid pests of stored grain throughout the grain growing regions of the world, in temperature gradients of $20^{\circ}-24^{\circ} \mathrm{C}, 20^{\circ}-30^{\circ} \mathrm{C}$, and $20^{\circ}-42^{\circ} \mathrm{C}$ in small bulks of wheat to determine their ecological preferences. Psocids consistently preferred the warmest regions of the gradients, except in the $20-42{ }^{\circ} \mathrm{C}$ gradients. Over 80 and $78 \%$ of psocids moved to the warmest region of the grain in the $20^{\circ}-24^{\circ}$ and $20^{\circ}$ $-30^{\circ}$ gradients, respectively. Liposcelis bostrychophila females and both sexes of $L$. paeta preferred the warmer region of the grain in the $20^{\circ}-42^{\circ}$ gradient, while densities of $L$. entomophila males were higher in more moderate temperature regions of the grain and densities of $L$. entomophila females were evenly split between the warm and hot regions of the grain. Temperatures can be below $20^{\circ} \mathrm{C}$ during much of the storage season for grains, so the current results help to explain why psocids move to warmer regions of the grain which occur toward the center of the grain mass as grain temperatures cool in the fall. This may allow psocid populations to continue to grow during the colder months.
\end{abstract}

Published by Elsevier Ltd.

\section{Introduction}

Psocids have become important pests of stored products during the last two decades internationally and during the last decade in the U.S. (Phillips and Throne, 2010), but little is known about their behavior or ecology. Psocids can damage intact grain (Athanassiou et al., 2010), and it can be difficult to control psocids in stored grain because many of the insecticides registered for use on stored grain are ineffective for control of psocids (Athanassiou et al., 2009) and because psocids in many countries are resistant to the fumigant phosphine that is used to disinfest stored grain (Nayak et al., 2003). Thus, effective management plans are essential for optimizing use of the control tactics available for psocids.

Opit et al. (2009) sampled psocids in two 1000-bushel (27 metric ton) steel bins of wheat over a 2-year period, and they showed that populations of psocids increased through the fall after the wheat was placed into storage in summer. Numbers of psocids captured were reduced in winter, but psocids were present in the

\footnotetext{
* Corresponding author. Present address: USDA, Agricultural Research Service, San Joaquin Valley Agricultural Sciences Center, 9611 South Riverbend Avenue, Parlier, CA 93648, USA. Tel.: +1 5595962702.

E-mail address: james.throne@ars.usda.gov (J.E. Throne).
}

grain year-round. During the fall and winter, more psocids were found in the center of the grain mass suggesting that the psocids moved away from the outside of the grain mass toward the warmer center of the grain mass as outside temperatures fell. Psocid species vary in their thermal requirements for development and reproduction, and this may influence their movement in stored grain. Knowing how different species of psocids respond to temperature gradients in grain may help us improve sampling and management methods for psocids as the temperatures in a grain mass change throughout the year. Our objective was to examine distribution of three of the most common pest species of psocids in temperature gradients to determine their ecological preferences.

\section{Materials and methods}

\subsection{Insects}

The psocid species used in the study are three of the main psocid pests of stored products throughout the grain growing regions of the world: Liposcelis bostrychophila Badonnel (Psocoptera: Liposcelididae), Liposcelis entomophila (Enderlein), and Liposcelis paeta (Pearman). Liposcelis bostrychophila is generally parthenogenetic, although a few males recently have been found (Mockford and 
Krushelnycky, 2008). Liposcelis paeta is unique in that populations can increase at temperatures as high as $42{ }^{\circ} \mathrm{C}$ (Rees and Walker, 1990). Psocid cultures were started with collections in Manhattan, KS, in 2005 and 2006, and voucher specimens were deposited in the Kansas State University Museum of Entomological and Prairie Arthropod Research under lot numbers 182 (L. entomophila), 202 (L. bostrychophila), and 207 (L. paeta). Cultures were reared on a mixture of $95 \%$ cracked Santa Fe hard red winter wheat, $2 \%$ wheat germ (Bob's Red Mill Natural Raw Wheat Germ, Milwaukie, OR), 2\% brewer's yeast (MP Biomedicals, Solon, $\mathrm{OH}$ ), and 1\% rice krispies (Kellogg's Company, Battle Creek, MI) at $30^{\circ} \mathrm{C}, 65 \% \mathrm{RH}$, and 16:8 L:D photoperiod.

\subsection{Gradient arenas}

We determined distribution of psocids in temperature gradients using a 60-cm-diameter circular arena with 9-cm high metal sides that holds $18.5 \mathrm{~kg}$ (2/3 bushel) of wheat (Flinn and Hagstrum, 2011). The arena had a 2-cm-thick wooden base and lid, both of which were covered with $3.5-\mathrm{cm}$-thick insulating foam on the outside. We used a removable metal divider to partition the arena into outer, middle, and inner rings during filling the arena with wheat and during removal of the wheat. There was a 4 -cm-diameter core in the center of the arena in which a heating element was inserted (see below), and the inner ring was $7.6-\mathrm{cm}$ wide and the middle and outer rings were $10.2-\mathrm{cm}$ wide. The middle and outer rings were split into four and eight cells, respectively, so that all 13 cells (the inner ring constituted one cell) held between 1.1 and $2.2 \mathrm{~kg}$ of wheat each. We filled all cells with $13.5 \%$ moisture content Santa Fe hard red winter wheat, and then we removed the divider from the wheat. We covered the arena with the lid, and then placed the arena in the dark in an environmental chamber maintained at $20^{\circ} \mathrm{C}$ and $65 \% \mathrm{RH}$. We heated water to the high gradient temperature $\left(24,30\right.$, or $\left.42^{\circ} \mathrm{C}\right)$ using a water bath (RTE 211, Neslab Instruments Inc., Newington, $\mathrm{NH}$ ), and then ran this heated water through a coil made of copper tubing in the center core of the arena to achieve the high gradient temperature at the center of the grain bulk. This resulted in the outside of the wheat in the arena being at $20^{\circ} \mathrm{C}$, the center of the wheat at the high gradient temperature, and a gradient of temperatures in between. We inserted temperature probes [YSI series 400 thermistor probes (YSI Incorporated, Yellow Springs, OH) read using a Digi-Sense thermistor reader (Cole-Parmer, Chicago, IL)] through small holes in the lid of the arena at 3.1, 6.2, 9.3, 12.4, 15.5, $18.6,24.8$, and $27.7 \mathrm{~cm}$ from the outer edge of the center core of the arena, and we measured temperatures of the wheat at the beginning and end of each replication to ensure that target temperatures were maintained while psocids were in the wheat.

After $48 \mathrm{~h}$ of temperature equilibration, we removed the lid from the arena and partially reinserted the divider to make impressions of the cells on the surface of the wheat. We then removed the divider, and added slightly different numbers of 1-2-week-old adult psocids to the surface of the wheat in each cell to achieve equal psocid densities (about 7 psocids/ $\mathrm{kg}$ of wheat) among the cells (ten psocids in outer cells, 12 in middle cells, and 15 in the inner cell for a total of 143 psocids).

After $24 \mathrm{~h}$, we reinserted the divider into the wheat, removed the wheat from each cell using a vacuum, sieved the psocids from the wheat using a U.S. standard \#10 sieve (2-mm hole size), sieved the material containing the psocids removed from the wheat using a U.S. standard \#30 sieve (0.6-mm hole size) to separate the psocids from broken wheat kernels which are retained on the sieve, and then counted the psocids from each cell. The arena was aired out for at least three days at $30^{\circ} \mathrm{C}$ between tests. There were three replications of each of three gradients $\left(20^{\circ}-24^{\circ}, 20^{\circ}-30^{\circ}\right.$, and $\left.20^{\circ}-42^{\circ}\right)$ and of a $30^{\circ}$ control (arena placed in the dark in an environmental chamber maintained at $30^{\circ} \mathrm{C}$ and $65 \% \mathrm{RH}$ ) tested for L. bostrychophila females and for males and females of $L$. entomophila and $L$. paeta. We initially tested the arenas to see if the response differed if the $20^{\circ} \mathrm{C}$ temperature was in the inner or outer ring of the arena, and the response was the same either way (data not shown).

\subsection{Data analysis}

We analyzed the data using the General Linear Models procedure in SAS (SAS Institute, 2008), and compared means using linear contrasts. We first calculated the density of psocids in each of the three rings (inner, middle, outer) at the end of a replication by dividing the number of psocids in each ring at the end of the replication by the weight of the grain in each ring (density = number of psocids/kg of wheat). We did this because the weight of the grain in each ring varied, but the proportion of psocids recovered also varied. Psocids are very small, and, thus, are difficult to find again when released in 2/3 of a bushel of wheat. Recovery rates varied from 37 to $95 \%$, and this was correlated with size of the insects (69-95\% for L. bostrychophila, $37-62 \%$ for L. entomophila males, $57-85 \%$ for L. entomophila females, $41-73 \%$ for L. paeta males, and $60-79 \%$ for L. paeta females). Males are smaller than females, and L. entomophila and $L$. paeta are smaller than $L$. bostrychophila. We then added the densities of psocids in the three rings in a replication together to give the total density in the arena, and divided the density in each of the three rings by the total density for the arena. This resulted in a proportion of the total density that was in each ring at the end of each replication, and these were data used in the analysis to test whether the final distribution of psocids in the arenas varied among the three rings.

\section{Results}

There was a tendency for psocids to move toward the inner and outer walls of the arena in the $30^{\circ} \mathrm{C}$ constant temperature control arenas (Fig. 1). Liposcelis bostrychophila females and L. paeta males were found at higher densities in both the inner and outer rings, while $L$. entomophila males and $L$. paeta females were found at higher densities in the outer ring. There were no differences in densities among the rings for $L$. entomophila females. Because of this tendency to move toward the walls, particularly the outer wall, we conducted tests with the higher and presumably more attractive temperature in the inner ring so that psocids would have to overcome any natural tendency to move toward the outer wall.

Psocids consistently preferred the warmest regions of the gradients, except in the $20-42{ }^{\circ} \mathrm{C}$ gradients. Over $80 \%$ of psocids moved to the warmest region of the grain in the $20^{\circ}-24^{\circ}$ gradients, although both sexes of $L$. entomophila also had higher densities in the middle ring than in the outer ring. Over $78 \%$ of psocids moved to the warmest region of the grain in the $20^{\circ}-30^{\circ}$ gradients, with both sexes of $L$. entomophila and $L$. bostrychophila females having higher densities in the middle ring than in the outer ring. Liposcelis bostrychophila females and both sexes of $L$. paeta again preferred the warmer region of the grain in the $20^{\circ}-42^{\circ}$ gradients, but densities of $L$. entomophila males were higher in the middle ring and lowest in the outer ring while densities of $L$. entomophila females were evenly split between the inner and middle rings.

The temperatures within a ring varied across each ring (Fig. 2). Across all replications, temperatures in the $20^{\circ}-24^{\circ} \mathrm{C}$ gradients varied from 19.7 to $20.5^{\circ}$ in the outer ring, 20.4 to $21.6^{\circ}$ in the middle ring, and 22.2 to $24.2^{\circ}$ in the inner ring. Temperatures in the $20^{\circ}-$ $30{ }^{\circ} \mathrm{C}$ gradients varied from 19.8 to $20.7^{\circ}$ in the outer ring, 21.2 to $24.4^{\circ}$ in the middle ring, and 26.0 to $30.3^{\circ}$ in the inner ring. Temperatures in the $20^{\circ}-42^{\circ} \mathrm{C}$ gradients varied from 19.5 to $22.0^{\circ}$ in the outer ring, 22.6 to $28.8^{\circ}$ in the middle ring, and 32.1 to $42.3^{\circ}$ in the 

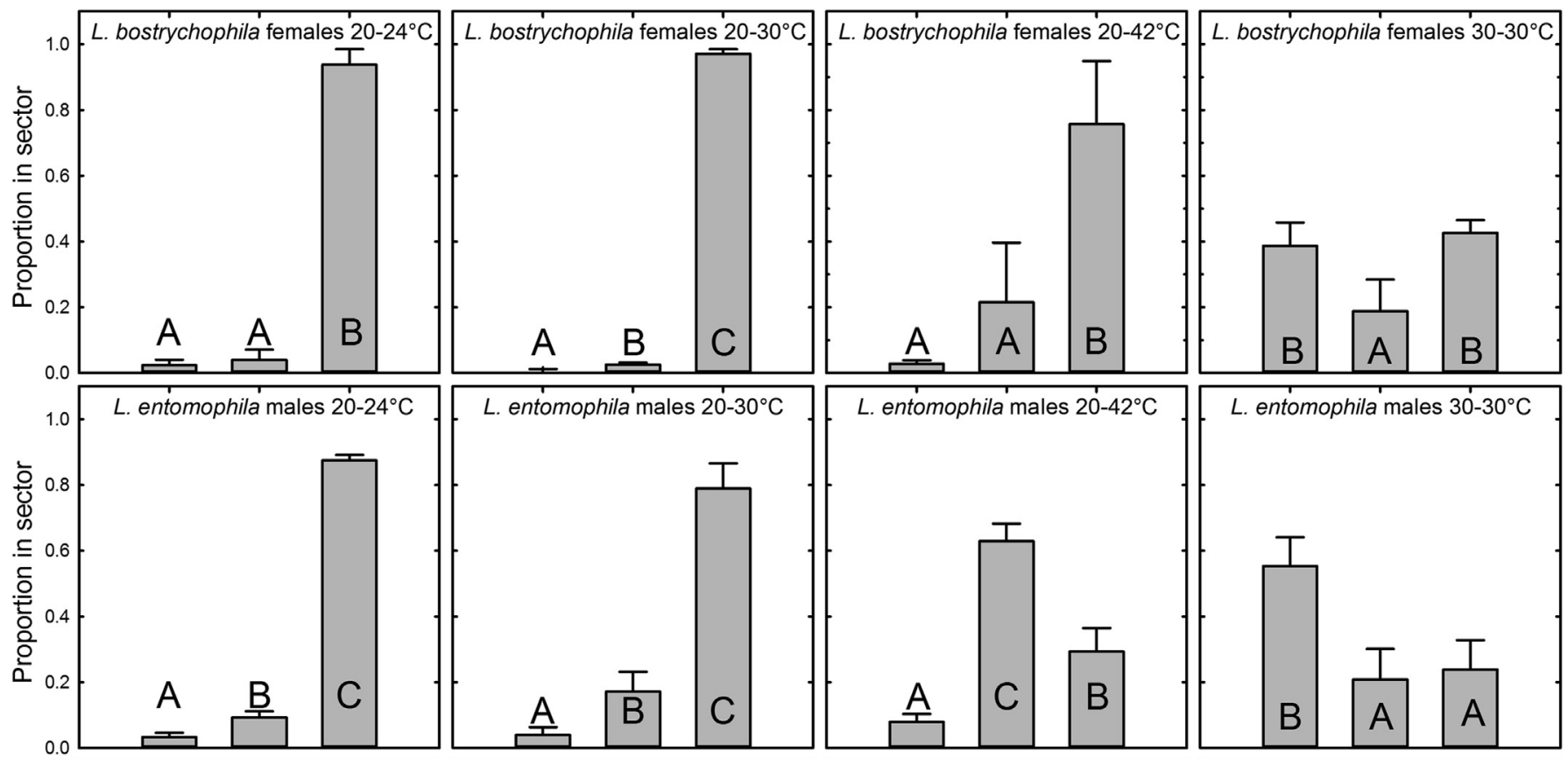

L. entomophila males $30-30^{\circ} \mathrm{C}$
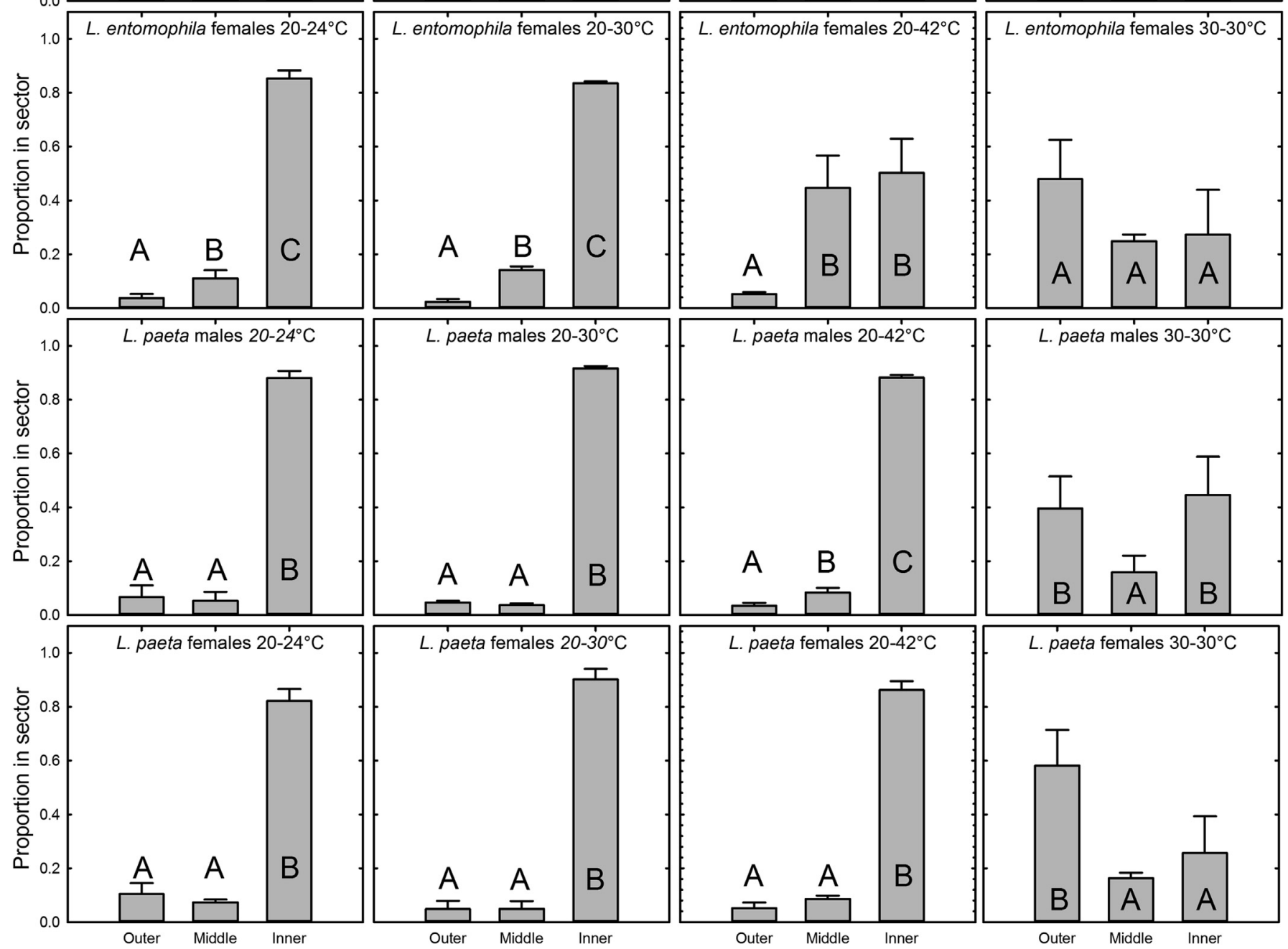

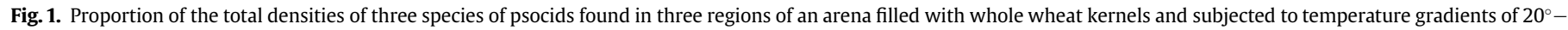

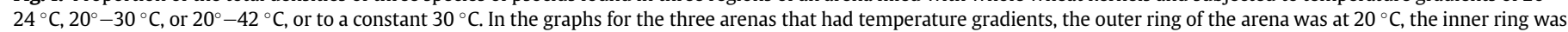
at the high temperature of the gradient, and the middle ring was at intermediate temperatures. 


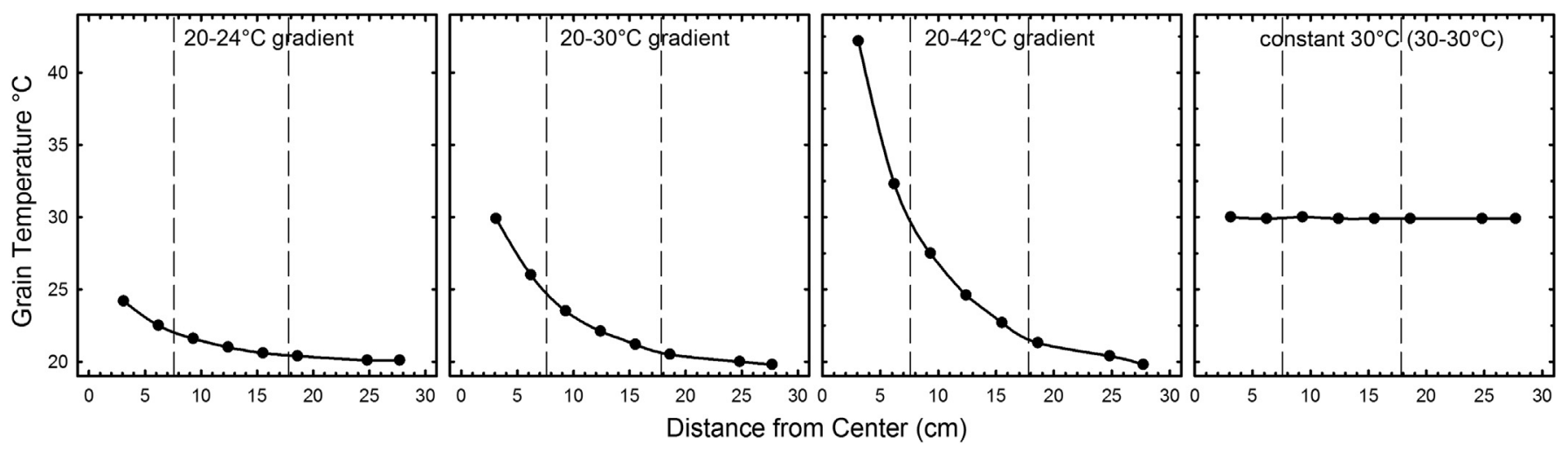

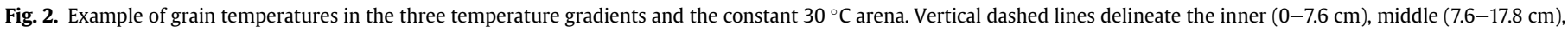
and outer rings $(17.8-28 \mathrm{~cm})$, and the black circles indicate the locations of temperature sensors.

inner ring. Temperature sensors were not placed at the edges of each ring (locations of temperatures sensors are shown as solid black circles in Fig. 2), but were offset from the edge, so the temperature ranges shown above for each gradient are not contiguous - i.e., there are gaps between the ranges because of the locations of the sensors.

\section{Discussion}

Although there was a tendency for psocids to move to the walls in the constant $30^{\circ}$ arenas, this tendency was overcome in the gradient arenas by their non-preference for $20^{\circ}$ grain. Having the inner ring of the arena at a higher temperature avoided any bias that psocids had to move to the outer wall, although there was also a tendency for $L$. bostrychophila females and $L$. paeta males to move to both the inner and outer walls in the constant temperature arenas. Despite this tendency, movement away from $20^{\circ}$ grain was always obvious.

It was not surprising that psocids moved away from the $20^{\circ}$ grain, which is near their lower developmental threshold. Liposcelis bostrychophila and L. entomophila can develop from egg to adult at $20^{\circ} \mathrm{C}$ (Wang et al., 1998, 2000), but L. paeta cannot (Wang et al., 2009). One would expect that cold-blooded organisms would prefer locations that would be more favorable for development of their progeny, and psocids, which are highly mobile, would be expected to adjust their location in a grain mass to find habitats more suitable for reproduction and development of their progeny. It is interesting that the psocids were able to detect even a four-degree temperature gradient $\left(20^{\circ}-24^{\circ}\right)$, and then move across a $60-\mathrm{cm}$ arena to the warmer region of the grain over a 24 -h period. Liposcelis bostrychophila and L. entomophila females have been recorded moving at velocities of 0.49 and $0.36 \mathrm{~cm} / \mathrm{s}$, respectively, on a flat surface (Guedes et al., 2008), so they could presumably traverse a $60-\mathrm{cm}$ flat surface in two to three minutes. Moving through grain interstices presumably would be slower. Rusty grain beetles, Cryptolestes ferrugineus (Stephens), were able to detect a one-degree temperature difference to move to the warmer region of the grain (Flinn and Hagstrum, 1998), and they have been shown to detect this difference within one hour in small bulks of wheat (Jian et al., 2004). The lesser grain borer, Rhyzopertha dominica (F.), showed no temperature preference after $24 \mathrm{~h}$ in a $20^{\circ}-24{ }^{\circ} \mathrm{C}$ gradient (Flinn and Hagstrum, 2011), but they did move to the warmer region of the grain after $96 \mathrm{~h}$. Lesser grain borers are less mobile than rusty grain beetles, which may explain their longer response time in a temperature gradient (Flinn and Hagstrum, 2011).

Response in the $20^{\circ}-30^{\circ}$ gradients was similar to that in the $20^{\circ}-24^{\circ}$ gradients, but response in the $20^{\circ}-42^{\circ}$ gradients differed with species. Liposcelis paeta is one of the few psocid species that can develop at $42{ }^{\circ} \mathrm{C}$ (Rees and Walker, 1990), and they preferred the hottest region of the grain. The hottest region of the grain in the $20^{\circ}-42^{\circ}$ arena was less preferred than the middle moderatetemperature region by $L$. entomophila males, which are small and, in general, appear less hardy than larger psocids - i.e., they are more likely to die during handling or when subjected to adverse temperatures or humidities. Larger $L$. entomophila females were evenly split between the warm and hot regions in the $20^{\circ}-42^{\circ}$ arena. Liposcelis bostrychophila females, which are larger and appear hardier than either sex of $L$. entomophila, preferred the hottest region in the $20^{\circ}-42^{\circ}$ arena. Neither L. bostrychophila nor L. entomophila survived at $39{ }^{\circ} \mathrm{C}$ or higher in constant temperature development studies (Rees and Walker, 1990).

Other stored-product insect pests tested for temperature preference, which were all beetles, showed responses similar to the psocids by preferring warmer regions of grain up to about $30^{\circ} \mathrm{C}$, but they differed in that none of the beetles preferred higher temperatures. For example, Deal (1941) showed this for Cryptolestes turcicus (Grouvelle), Lasioderma serricorne (F.), Oryzaephilus mercator (Fauvel), Oryzaephilus surinamensis (L.), Sitophilus granarius (L.), Sitophilus oryzae (L.), and Tribolium confusum (Herbst), and Flinn and Hagstrum $(1998,2011)$ showed this for $C$. ferrugineus and $R$. dominica. Thus, psocids appear to have species that are adapted over a broader range of moderate to high temperatures than some of the stored-product beetle pests.

A study on temporospatial distribution of psocids in 1000bushel steel bins of wheat (Opit et al., 2009) showed that more psocids [Liposcelis decolor (Pearman) and L. entomophila] were found in the center of the surface of the grain mass and at a greater depth as grain temperatures dropped in the fall. The center of the grain surface and grain at lower depths both had higher temperatures relative to the surface and the periphery of the grain. Thus, as in our arenas, the psocids appeared to seek out higher temperatures in bins of grain. Temperatures at the grain surface can exceed $45^{\circ} \mathrm{C}$ in summer (Longstaff and Banks, 1987), so psocids would be expected to move away from the surface at least during the day. Similarly, psocids have been observed leaving grain bins when the relative humidity in the bin drops over the course of a day, and Rees (2003) suggested that the female psocids, in particular, are leaving the bin to obtain moisture needed for egg production. They then return to the bin when the humidity in the bin rises.

Psocids, which can move at a rate of $0.5 \mathrm{~cm} / \mathrm{s}$, readily seek out regions of the grain mass with more favorable temperatures. The preferred temperatures vary with psocid species, but all species tested preferred $24^{\circ}$ or $30^{\circ} \mathrm{C}$ grain to $20^{\circ} \mathrm{C}$ grain. Grain temperatures often are below $20^{\circ} \mathrm{C}$ in bins of stored wheat in the central plains region of the U.S. (Opit et al., 2009), but also even in the 
southern U.S., where $55-85 \%$ of temperatures recorded in bins of stored corn were below $20{ }^{\circ} \mathrm{C}$ during a normal storage season (September to June) (Arbogast and Throne, 1997). Thus, psocids probably need to adjust their location in a grain mass throughout much of the storage season to locate areas suitable for population growth. The response to $32^{\circ}-42^{\circ}$ grain in the inner ring of the $20^{\circ}-$ $42^{\circ}$ gradient varied with species. For example, L. paeta, that develop well at high temperatures, preferred this hot region of the grain while this grain was too hot for some species, such as L. entomophila. The response to stimuli often varies with psocid species. For example, some species of psocids develop best at 70$80 \%$ relative humidity (Rees and Walker, 1990), while others, such as Liposcelis brunnea Motschulsky, develop better at 63\% relative humidity (Opit and Throne, 2009). Response to insecticides can also vary with psocid species. For example, it took four times as much of the fumigant sulfuryl fluoride to kill eggs of $L$. paeta than to kill eggs of Lepinotus reticulatus Enderlein (Psocoptera: Trogiidae) (Athanassiou et al., 2012). Thus, as with other stimuli, the response to temperature gradients varies with psocid species.

\section{Acknowledgments}

We thank George Opit for reviewing an earlier version of the manuscript, and Ken Friesen and Ann Redmon for excellent technical assistance. Mention of trade names or commercial products in this publication is solely for the purpose of providing specific information and does not imply recommendation or endorsement by the U.S. Department of Agriculture. USDA is an equal opportunity provider and employer.

\section{References}

Arbogast, R.T., Throne, J.E., 1997. Insect infestation of farm-stored maize in South Carolina: towards characterization of a habitat. Journal of Stored Products Research 33, 187-198.

Athanassiou, C.G., Arthur, F.H., Throne, J.E., 2009. Efficacy of grain protectants against four psocid species on maize, rice and wheat. Pest Management Science $65,1140-1146$

Athanassiou, C.G., Opit, G.P., Throne, J.E., 2010. Influence of commodity type, percentage of cracked kernels, and wheat class on population growth of storedproduct psocids (Psocoptera: Liposcelidae). Journal of Economic Entomology 103, 985-990.
Athanassiou, C.G., Phillips, T.W., Aikins, M.J., Hasan, M.M., Throne, J.E., 2012. Effectiveness of sulfuryl fluoride for control of different life stages of stored-product psocids (Psocoptera). Pest Management Science 105, 282-287.

Deal, J., 1941. The temperature preferendum of certain insects. Journal of Animal Ecology 10, 323-356.

Flinn, P.W., Hagstrum, D.W., 1998. Distribution of Cryptolestes ferrugineus (Coleoptera: Cucujidae) in response to temperature gradients in stored wheat. Journal of Stored Products Research 34, 107-112.

Flinn, P.W., Hagstrum, D.W., 2011. Movement of Rhyzopertha dominica in response to temperature gradients in stored wheat. Journal of Stored Products Research 47, 407-410.

Guedes, R.N.C., Campbell, J.F., Arthur, F.H., Opit, G.P., Zhu, K.Y., Throne, J.E., 2008. Acute lethal and behavioral sublethal responses of two stored-product psocids to surface insecticides. Pest Management Science 64, 1314-1322.

Jian, F., Jayas, D.S., White, N.D.G., 2004. Movement and distribution of adult rusty grain beetle, Cryptolestes ferrugineus (Coleoptera: Laemophloeidae), in stored wheat in response to different temperature gradients and insect densities. Journal of Economic Entomology 97, 1148-1158.

Longstaff, R.A., Banks, H.J., 1987. Simulation of temperature fluctuations near the surface of grain bulks. Journal of Stored Products Research 23, 21-30.

Mockford, E.L., Krushelnycky, P.D., 2008. New species and records of Liposcelis Motschulsky (Psocoptera: Liposcelididae) from Hawaii with first description of the male of Liposcelis bostrychophila Badonnel. Zootaxa 1766, 53-68.

Nayak, M.K., Collins, P.J., Pavic, H., Kopittke, R.A., 2003. Inhibition of egg development by phosphine in the cosmopolitan pest of stored products Liposcelis bostrychophila (Psocoptera: Liposcelididae). Pest Management Science 59, 1191-1196.

Opit, G.P., Throne, J.E., 2009. Population growth and development of the psocid Liposcelis brunnea (Psocoptera: Liposcelididae) at constant temperatures and relative humidities. Journal of Economic Entomology 102, 1360-1368.

Opit, G.P., Throne, J.E., Flinn, P.W., 2009. Temporospatial distribution of the psocids Liposcelis entomophila and L. decolor (Psocoptera: Liposcelididae) in steel bins containing wheat. Journal of Economic Entomology 102, 1369-1376.

Phillips, T.W., Throne, J.E., 2010. Biorational approaches to managing stored-product insects. Annual Review of Entomology 55, 375-397.

Rees, D., 2003. Psocoptera (psocids) as pests of bulk grain storage in Australia: a cautionary tale to industry and researchers. In: Credland, P.F., Armitage, D.M., Bell, C.H., Cogan, P.M., Highley, E. (Eds.), Proceedings of the 8th International Working Conference on Stored Product Protection, 22-26 July 2002, York, UK. CAB International, Wallingford, UK, pp. 59-64.

Rees, D.P., Walker, A.J., 1990. The effect of temperature and relative humidity on population growth of three Liposcelis species (Psocoptera: Liposcelidae) infesting stored products in tropical countries. Bulletin of Entomological Research 80, 353-358.

SAS Institute, 2008. SAS 9.2 for Windows. SAS Institute Inc., Cary, NC.

Wang, J., Zhao, Z., Li, L., 1998. Studies on bionomics of Liposcelis entomophila (Psocoptera: Liposcelididae) infesting stored products. Entomologica Sinica 5, 149-158.

Wang, J., Tsai, J.H., Zhao, Z., Li, L., 2000. Development and reproduction of the psocid Liposcelis bostrychophila (Psocoptera: Liposcelididae) as a function of temperature. Annals of the Entomological Society of America 93, 261-270.

Wang, J., Ren, Y., Wei, X., Dou, W., 2009. Development, survival, and reproduction of the psocid Liposcelis paeta (Psocoptera: Liposcelididae) as a function of temperature. Journal of Economic Entomology 102, 1705-1713. 